\title{
POTENTIAL FOR JOB CREATION AND RESOURCE DEPENDENCE IN RURAL FINLAND
}

\author{
Olli Lehtonen ${ }^{1}$, Markku Tykkyläinen²
}

Received 22 September 2013; Accepted 14 March 2014

\begin{abstract}
Despite strong secular economic growth after the crisis of 1990-93, most of rural Finland has continued to face severe job losses. By applying small-area analysis, this paper seeks to explain why some rural areas inevitably experience declining employment while others prosper and grow even faster than urban areas. The variation of job creation in rural small areas derives from local economic conditions, local demographic structure, proximity to larger centers, and natural conditions. Contrary to expectations, the coldest areas with nature reserves have passed the worst job loss. Those areas had a lower burden of declining primary industries than traditional agro-forest areas, and because of tourism, industry has expanded in some places in Lapland. The dependence of an area on the primary sector is a good indicator of the highest rural job losses during the urban-centric economic growth period. Especially the most resource dependent areas have lagged behind and fail in job creation on account of their uncompetitive industrial environment. Persistent labor surplus plagues such areas, implying that established policy measures have been unable to restructure and modernize traditional rural areas. Since Finnish rural and regional policies have been being inefficient they should be reformed especially in resource-based areas in a fundamental way.
\end{abstract}

Keywords: Job creation, resource dependence, rural areas, regional policy, Finland

Tiivistelmä: Huolimatta vahvasta talouskasvusta vuosien 1990-93 kriisin jälkeen, useimmat maaseutualueet kärsivät kasvukaudella vakavista työpaikkojen menetyksistä Suomessa. Tässä tutkimuksessa tarkastellaan pienaluetasolla syitä, miksi osa maaseutualueista kärsi talouden kasvukaudella työpaikkojen vähenemisestä vaikka toiset maaseutualueet menestyivät ja kasvoivat jopa nopeammin kuin useat kaupunkialueet. Tulosten perusteella työpaikkojen lukumäärän muutokset ovat yhteydessä maaseutualueiden paikallisiin taloudelliset olosuhteet, väestörakenteeseen, läheisyyteen suurempiin kasvaviin keskuksiin ja luonnonolosuhteisiin. Odotusten vastaisesti maaseutualueet, joille on tunnusomaista kylmä ilmasto sekä luonnonsuojelualueiden suuri osuus maapinta-alasta, ovat välttäneet pahimmat työpaikkojen lukumäärän menetykset. Menestystä selittää se, että näiltä alueilta puuttuu perinteisten supistuvien alkutuotantoelinkeinojen taakka

\footnotetext{
${ }^{1}$ Olli Lehtonen, Researcher, Department of geographical and historical studies, University of Eastern Finland, P.O. Box 111, 80100 Joensuu; e-mail: olli.lehtonen@uef.fi

${ }^{2}$ Markku Tykkyläinen, Professor of rural research, Department of geographical and historical studies, University of Eastern Finland, P.O Box 111, 80100 Joensuu; e-mail: markku.tykkylainen@uef.fi
} 
sekä se, että matkailu on paikoin kasvanut erittäin voimakkaasti Lapissa. Riippuvuus alkutuotannosta onkin hyvä indikaattori suurimmille työpaikkojen lukumäärän menetyksille kaupunkikeskeisenä kasvukautena. Varsinkin eniten resurssiriippuvaiset alueet ovat kokeneet eniten menetyksiä ja epäonnistuneet työpaikkojen luomisessa alueen alhaisen kilpailukyvyn vuoksi. Tämä osoittaa, että poliittiset toimenpiteet eivät ole kyenneet uudistamaan ja nykyaikaistamaan perinteisiä maaseutualueita. Tehotonta maaseutu- ja aluepolitiikkaa pitäisikin tulosten perusteella muokata perusteellisesti erityisesti resurssiriippuvaisilla alueilla.

Avainsanat: Työpaikkojen lukumäärän kehitys, resurssiriippuvaisuus, maaseutu, aluepolitiikka, Suomi

\section{Introduction}

As the economic evolution proceeds and the conditions for development change, the paradigms of local economic development evolve. In the Finnish case, the paradigm of development advanced from the colonization (1945-65) to the industrialization of the less developed parts of the country (from 1966 onwards) and to the promotion of clusters of high-technology industries (from the 1990s onwards). As regards the last paradigm, Suorsa (2007) concluded that its measures failed to reach peripheral regions and even decreased their opportunities. The long period of strong economic growth after the economic recession of 1990-93 did not abolish the problem of rural job loss (OECD 2009; Pyöriä, Melin, and Blom 2005: 35). At that time, Finland underwent very rapid evolution from a natural resource-based economy to a technology-driven one; the production growth was urban-centric and came mainly from electronics industries. Economic growth was strongly rooted in the production and distribution of new knowledge bolstered by innovation-led industrial policies (Foray and Lundvall 1996; Hartog, Boschma, and Sotarauta 2012; OECD 1996). In addition to the inflow of subsidies from the EU since 1995 to agriculture and less-favored areas, new integrated and project-based rural policy measures were implemented (OECD 2009). Farms in rural areas faced pressure to rationalize further inasmuch as support was allocated to efficient production (Voutilainen, Vihinen, and Wuori 2009: 83-85). The forest sector faced competition from the tropics and subtropics, where the rotation periods of forestry are much shorter and labor costs lower. Hence, the challenge for job creation was very high in rural areas in the booming period.

The economic recovery from late 1993 onwards led to the expectation of improving competitiveness and growth in rural Finland, but this expectation was too optimistic. Analyses of aggregate data at the municipal and regional levels suggest that the productivity increase and business closures in the primary sector overrode all the other job growth and the geographical concentration of industries accelerated, all of which caused outmigration and an ageing population in rural areas (Gløersen et al. 2005). It was not only Finland, but also other sparsely populated areas in Northern Europe that experienced high labor surplus and relatively low incomes (Gløersen et al. 2005). Rural Canada faced comparable problems (e.g. Overdevest and Green 1995; Partridge et al. 2009; Patriquin, Parkins, and Stedman 2007; Stedman, Parkins, and Beckley 2004, 2005).

Rural population decline means a zero-sum demographic game for settlement systems in many industrialized countries with a relatively stable national population (Polèse and Shearmur 2006a). Evidence from various countries shows that some rural areas are in better positions than others to create jobs, because areas differ markedly in the mix of industrial activities, natural and human resources, relative locations, and demographic and social attributes (Bryden and Bollman 2000). In addition to applying such a conventional analysis of the factors of job creation, a test was applied to show how the legacy of natural resource dependence predicts rural growth and decline in jobs. To fill the research gap concerning small-area analysis, this paper analyzes at the postcode area level how the preconditions for job creation in rural areas are related to the local economic environment, demography, relative location, and natural conditions. The paper shows how these preconditions explain why some rural areas in Finland have inevitably experienced declining employment and depopulation while others have prospered and grown even faster than urban areas. It investigates in a more detailed way why 
job creation has been especially problematic in rural areas and discusses what could cause the growth differences. The study unravels the unexplored small-area dynamics of Finnish rural areas in job growth and job loss during the cluster-based innovation policy era of $1994-2003$ after the 1990 - 1993 recession.

\section{Economic growth and economic change in a rural setting}

\subsection{Spatial economic evolution}

Cost effects on profits crucially impact industrial location. Polèse and Shearmur (2006b) theorized the formation of the Canadian economic landscape, showing that the economic landscape is a trade-off between the centralizing effects of agglomeration economies and the dispersal effects of congestion and falling transport costs. One explanation for the spatial rural-urban dynamics is to be found in the studies of spatial competitiveness and spatial equilibrium, which show how a core-periphery economy has to adapt to this situation either by changing its spatial cost structures, by providing better competitiveness or higher rural utility through amenities, or by accepting migration (Irvin et al. 2010; Olfert and Partridge 2010). Pekkala (2003) analyzed adaptation and showed that rural-urban migration in Finland is a result of higher wages and better employment prospects in urban areas. A shift away from the high labor shares in primary production and resource processing is inevitable as productivity increases and the production of many agricultural basic products grows slowly or not at all. As growing industries focus on using more production factors of a kind other than traditional areal ones, the geographical pattern of industry changes radically.

Resource-based industrialization, productivity increase in the primary sector, and the spread and backwash effects of growth were important elements for growth and subsequent decline in Finnish rural areas for over a century (Hjerppe 1989; Tervo 2009; Tervo 2010). Spread effects have been an argument for urban-centric development policy to be accepted in a rural setting almost everywhere (Irving et al. 2010; Tervo 2005). Partridge et al. (2007) unveiled the topography of widespread effects in the Canadian context. From the late 1980s, the Finnish regional policy altered towards attempts to promote technology-driven clusters, such as information and communications technology (ICT) clusters, and learning regions (OECD 2008; Vartiainen and Viiri 2002). Finnish policy makers followed the mainstream theory directions that knowledge has become a central factor for economic growth and improved well-being (Castells 2000; Cooke and De Laurentis 2002; Cooke and Leydesdorff 2006; Maskell and Malmberg 1999). In this view, economic development emerges from knowledge and the growth of inputs from research and development (R\&D), which is fairly urban-centric (Danson 2009). Nevertheless, many studies have revealed that smaller centers, which most Finnish urbanizations are, lack the conditions of scale economies to sustain growth (Gløersen et al. 2005; Laakso and Loikkanen 2004: 113-116).

Growth targeted a handful of major Finnish cities recovered rapidly from the recession (Castells and Himanen 2002: 10-18; Heikkilä and Pikkarainen 2010; Lehtonen and Tykkyläinen 2010). It happened in parallel with a restructure of the rural resource-based economy, in which labor productivity increased more than the demand for products. This industrial restructuring can be abstracted to the situation in which a productivity increase in primary production empties the peripheries, the conditions for redevelopment are poor, and the first priority in economic development policy measures has been given to non-spatial economic efficiency. According to the logic of spatial dynamics, the impacts of agglomeration economies attenuate and hence the economic performance of many industrial sectors declines with increasing distance from cities, as shown in many studies (Irwin et al. 2010; Partridge and Rickman 2008; Polèse and Shearmur 2004).

Contrary to urban competitiveness, the competitiveness of rural areas generally consists of assets such as cheap land, access to non-urban resources, place commitment, and natural amenities (Markey, Halseth, and Manson 2006). The barriers to competitiveness are a stagnant economic base, low levels of education, an aging and declining population, and declining employment. Many elements of competitiveness demanded by growing industries are very poorly developed in comparison with those in urban areas (Kitson, Martin, and Tyler 2004). 
A European problem, contrary to North America, is high unemployment in rural areas and significant regional differences in economic performance (Puga 2002). It makes sense to ask whether there is something specific in socio-economic compositions, urban-rural structures, or the nature of North European peripheral rural areas.

\subsection{Factors of rural job creation}

To understand various factors affecting rural employment in Finland, the regression technique was applied using rural postcode areas as observational units. In this section, the theoretical foundations for the selection of the explanatory factors of rural job creation for the analysis are presented. For the first hypotheses, the explanatory variables for job creation consist of four groups of different potential factors of job growth that is in line with the summary of Bryden and Bollman (2000: 186). The hypothesis assumes that job growth is determined by local economic and demographic factors, the proximity of rural postcode areas to urban centers, and natural environment and amenity factors. After that, the paper outlines how the institutions of mature economic structures impact on job creation. According to the second hypotheses, the institutions of mature resource-based local economy explain the residual variance of the regression models of job creation found in the testing of the first hypothesis.

\section{Economic and demographic factors}

Theoretically, it is evident that a labor pool with entrepreneurship provides opportunities for job creation. Stephens and Partridge (2011) found that a high proportion of self-employment generates employment; hence, the proportion of non-farming entrepreneurs may predict job creation in rural areas. As higher incomes indicate active participation in economic activity, it was worth investigating whether the income level would be an indicator of activity and capabilities that would impact on job creation in the rural setting.

It was presumed that during a long spell of economic growth, the demand for labor diffuses to rural areas and utilizes the redundant labor force as much as possible. As the worst areas have the relatively largest available pool of labor, the impact of economic growth could be expected to lower the unemployment rate in these areas the most during long boom periods. Creativity and interaction constitute a seedbed of the supply for versatile skills and subsequent economic growth. A one-sided industrial structure may retard industrial renewal and therefore the degree of industrial specialization was considered to affect the propensity for job growth. Industrial specialization is measured by the simple location quotient (SLQ) and the Herfindahl index. Growing industries demand labor and hence age cohorts are assumed to have different impacts on job creation. Usually, a higher educational level and higher population density promote job growth, but as this analysis concerns rural areas only, this dependence may be less obvious (Shearmur and Polèse 2007).

\section{Proximity to urban networks}

Since proximity to agglomeration economies matters globally, the explanatory power of distance from urban networks was tested with different variables. High interaction density would be very much in line with the new economy, requiring frequent travel related to customer or supplier relations and the use of multifaceted city infrastructures - airports, universities, technical schools, etc. - as Polèse and Shearmur (2006a) showed. According to Partridge et al. (2008a, $2008 \mathrm{~b}$ ), the distance from higher-tiered urban areas is important for rural areas. A possible reason for the spatial link of smaller centers with larger ones is the need for the complementary specialized services found only in larger cities. They also found that increasing the population size of the nearby higher-tiered city has a much smaller effect than changing its distance from the lower-tiered city, further suggesting that it is access to urban services that is especially beneficial. This gives a good reason to assume that rural job creation and job loss are dependent on connectivity to the urban-centric service network and its density.

Population and jobs appear to be concentrated in the higher-tiered urban areas, namely metropolitan areas, and larger cities and their adjacent areas (Hobbs and Stoops 2002; Krätke 2007; Partridge et al. 2008a). Between 1994 and 2005, in total 66.9 percent of the job growth in 
the Finnish rural municipalities was concentrated on those adjacent to urban ones and 33.1 percent in robust agriculture-dominated core rural municipalities (Malinen et al. 2006; Figure 1). The vast hinterlands, sparsely populated rural municipalities, lagged behind in development as the number of jobs declined over the same period. These figures appear to suppose that job creation and job loss were dependent on connectivity to urban labor markets.

The spatial concentration of production, once it has started in an auspicious region with an initial advantage, such as a natural or constructed advantage, will be stronger the lower the transportation costs and the stronger the economies of scale are, and it will then attract labor from less competitive localities (Cooke and Leydesdorff 2006; Krugman 1991). Tervo (2009) found somewhat more evidence for backwash effects than for spread effects in Finland in 1970 - 2004. His study unveiled that rapidly growing, large regional urban centers had backwash effects, while slowly growing regional centers and small regional centers had spread effects. Various distance factors, city size and urban growth in the population, jobs and incomes, and spatial linking measured by incremental distance are assumed to explain rural job creation.

\section{Natural conditions and amenities}

A less discussed factor of rural development is the natural environment, consisting of factors such as climate, topography, and soil. These factors are important because industrial development tends to locate in areas with favorable natural conditions (Gallup, Sachs, and Mellinger 1999; Gløersen et al. 2005; Sachs and Warner 1997), which indicates the tendency of a socio-economic system to adapt to the environment geographically (Partridge, Olfert, and Alasia 2007). Natural conditions and amenities facilitate migration to places endowed with high levels of natural amenities, low living costs, and good economic opportunities (Deller et al. 2001; Tuhkunen 2007; Partridge 2010). Isolated human systems in cold environments are expensive to maintain (Hill and Gaddy 2003), because the cost structures of the production and settlements are unfavorable. In the Finnish case, the advantages that "first nature" provide were decisive in the emergence of resource-based activities, but their development and diffusion to inland was boosted by government policy measures. The most diversified economies exist in places with temperate climatic conditions in the south and on the coast, as forestry and smallerscale agriculture prevail in less advantageous, colder inland environments. Production and housing preferences have changed dramatically since the times of resource frontier expansion and it is suggested that climatic conditions, terrain, land use, and leisure time activities influence new ways of job creation.

\subsection{Resource dependence as a sign of retarding factors in industrial transformation}

Apart from the modern production chains of resource industries, resource-based areas are distant from developing economic environments. The evolution of social institutions accounts for economic progress (Ruttan and Hayami 1984; North 1991; Raiser 2001; Bosma and Schutjens 2011). Kosonen (1995) and Kalugina (2007) showed in Russia how slowly social institutions evolve in a stagnant society. Kosonen called this slowness the institutional lag, which shows that technological changes and economic inventions are persistently one step or more ahead of the inherited social institutions. This social inertia plagues communities in their mature industrial stage (Ayres 1962; Lindstrom 1964; Martin and Sunley 2006). The more socio-economically distant the area is from an advanced institutional environment, the larger is this gap. Stenholm et al. (2013) found in a cross-country comparison that less regulative institutional environments promote entrepreneurial activity more than cognitive and normative factors. Rodriquez-Pose and Frateri (2007) concluded that peripheral areas in southern Europe have become increasingly dependent on subsidies and detached from the market, which little by little erodes their capacity to compete in a more integrated market. They refer to such a business environment, which slows down institutional and industrial renewal, as sheltered.

Various forms of government support have maintained primary production activities and relatively high rural populations in Finland for decades and even longer. The skills of most rural entrepreneurs and employees are involved in primary production and service occupations, innovations are rare, the educational level is low, and the share of people living on welfare 
payments is high. Poor rural job development may be very closely associated not only with poor accessibility and useless physical locational factors for advanced industries, but also with theinstitutional legacy of past mature industries and their cultural and socio-economic environments. Entrepreneurial traditions differ geographically (Koski 2002) and welfare policy and development policy can be contradictory in less-developed areas (Jauhiainen 2008). The second hypothesis suggests that such institutional legacy explains, at least in part, the slow transformation of industrially mature one-sided agro-forest areas.

In an earlier study of eighteen case studies in nine EU member states, Terluin and Post (2000) concluded that the more rural a locality is, the more disadvantaged it will be in terms of economic transformation due to its poor cultural and social capacities for restructuring and growth. This regularity can be interpreted as the primary sector possibly being the only sector in which there are business opportunities rooted in the given attributes of the region (Polèse and Shearmur 2006a) and the one-sided resource-based socio-economic structure failing to offer competitive advantages for diversification. Job creation in the advanced industries cannot benefit much from such rural conditions in which only primary production survives.

\section{Empirical models and observational unit}

\subsection{Selection of models and estimation techniques}

As the purpose of the study is to acquire new insights into the factors of job creation at the rural small area level excluding the urban areas, the research design was planned to be explorative. At first, hierarchical regression analyses were constructed using several independent variables from which the significant growth factors were selected for the final models. Ordinary least squares (OLS) regression was used as it has been successful in many other studies. To be comprehensive, regression analyses were designed to include for revealing the possible spatial autocorrelative impacts of the factors influencing job creation. The logistic regression model was selected as it is easy to interpret the results in a simple way in the case if the results are dichotomous.

The model in the testing of the first hypothesis had a considerable residual variance which seemed to be related to primary production areas. Hence, we concentrated on explaining in a simple way how the mature resource-based economic structures explain the residual variance found in the testing of the first hypothesis. For this purpose, the model was based on a nonparametric regression surface on which resource dependence is "explained" by the change in the number of jobs and deviations from success as quantified by the residuals. The nonparametric analysis analyzes relations without assuming an underlying theoretical distribution being thus flexible to explain a priori fully unknown associations.

\subsection{Empirical models of the factors of job creation}

The dependent variable is measured by the percentage change in the number of jobs over the period 1994 - 2003 by rural postcode area. The analysis attempts to trace the local socioeconomic conditions of job creation by capturing the associations revealed by ordinary least squares (OLS), spatial error, and logistic regression models. The model defined in its general form is

$$
\% \triangle J O B_{i}=\alpha+\lambda \mathrm{ECONOMY}+\phi \mathrm{DEMOGRAPHY}_{i}+\delta \mathrm{LOCATION}_{i}+\varphi \mathrm{AMENITY}_{i}+\varepsilon_{i}(1)
$$

where ECONOMY, DEMOGRAPHY, LOCATION, and AMENITY are vectors that represent the economic and demographic characteristics of each rural postcode area $(i=1, \ldots 1157)$, its proximity to urban networks, and its natural conditions and amenities. Detailed definitions and units for the variables are presented in Table 1 in the Appendix. The independent variables indicating a change concern the period of 1994 - 2003 and most variables for a single year depict the year 2003. The data from 1994 was incomplete and thus the independent variables describe the end-period characteristics of post code areas. Some of the variables have been transformed with the square root to fit normal distribution for analysis, as performed by Partridge 
et al. (2007). A violation of the assumption of normality could have led to estimation errors in the hypothesis testing.

The regression coefficients are estimated for the set of different regression models for comparison and to obtain a view of the stability of the results. The models are fitted by ordinary least squares (OLS, models 1 - 4) regression, spatial error regression (with spatial lags of $20 \mathrm{~km}$ and $85 \mathrm{~km}$, models $5-6$ ), and a logistic regression model (model 7) (see details of the model as presented by Anselin 1990). ${ }^{3}$ As various socio-economic neighborhood effects and clustered geographical patterns may emerge and influence the economic conditions, two spatial lag lengths were used. The spatial lag variables will reveal whether a change in the number of jobs is a result of the spatial clustering of the explanatory phenomena. The spatial lag of $20 \mathrm{~km}$ depicts the impacts of the main commuting neighborhoods (Helminen et al. 2003), whereas the larger spatial lag of $85 \mathrm{~km}$ adds the effects of very rural areas between centers job creation (Helminen et al. 2003). It is considered these two area types are relevant to the comparison because the spatial patterns of the factors of rural job creation are unknown.

\subsection{Capturing empirically the problem of retarding factors}

The high significance of the SLQ of primary production in the models in the testing of the first hypothesis stimulated the investigation of the role of resource dependence in detail and in a way that has not previously been attempted. What would be the unexplained factor behind the linear models and the logit model? As each model left much of the variance unexplained, it was worth studying whether the residuals contain variation that could be explained by the proxy variable of the institutional lag, the resource dependence. If the research setting reveals that the association with primary production is even harder than the simple models predict, to be successful in terms of increasing numbers of jobs, very resource-dependent areas should overcome the retarding attributes linked to a one-sided socio-economic structure with a greater effort than otherwise similar but less resource-dependent areas. The indicator of resource dependence is the sum of employment in agriculture, forestry, and fishing as a proportion of the total number of employed persons in a postcode area.

The idea of the second hypothesis was inspired by earlier studies that showed the covariation between resource dependence and poor local economic development and the lack of dynamism in sheltered economies (Rodriquez-Pose and Frateri 2007; Terluin 2003). In a similar vein, case studies in transitional countries have revealed the slow pace of institutional and socio-economic modernization in collapsing business environments in both rural and urban settings (Kosonen 1995, 2002; Piipponen 2006). These growth-retarding findings are tested based on a nonparametric regression surface on which resource dependence is "explained" by the change in the number of jobs and deviations from success as outlined by the residuals $(\varepsilon)$ in equation 1 and applied in models $4-7$. The negative residuals are interpreted as capturing the retarding properties of the economic performance of a rural area that are induced by resource dependence. If a residual $\left(\varepsilon_{i}\right)$ is positive at a certain level of resource dependence, the area has succeeded better in terms of jobs than its properties would suggest, and if a residual is negative, the area has performed less well than its properties would suggest. The position of the values of resource dependence in the $\Delta$ Jobs-Residual coordinates reveals the impact of resource dependence on job creation.

The four non-parametric regression surfaces were estimated with the Nadaraya-Watson estimator to expound the residuals of models 4-7. This estimation technique allows an explorative data analysis without simplifying the data structures, therefore showing diverse relationships in the data (e.g. Faraway 2006). If resource dependence with its underlying factors

\footnotetext{
${ }^{3}$ Models:

OLS $y=X \beta+e$

Spatial error $y=X \beta+\varepsilon$, where $\varepsilon=\lambda W \varepsilon+\xi$

Logistic $y=\frac{e^{y}}{e^{y}+1}$, where $y=X \beta+\varepsilon$
} 
affects the development of the rural areas, the observed values defining resource dependence will not be located randomly around the $\Delta$ Jobs-Residual relation.

Finally, to be able to test this hypothesis statistically, a permutation test was created where the observed empirical surfaces of four regression variants were evaluated against the permutated resource-dependent surface. This computing intensive test allows the unveiling of whether resource dependencies on the non-parametric surface are generated randomly or not. The permutations were performed by keeping the residuals and the changes in the number of jobs constant but permuting the values for the resource dependence randomly with respect to the surface without replacement from the distribution $U$, which consists of values depicting the resource dependence in every postcode area. The permutations were performed using exactly the same values for the bandwidth and evaluation points with the Nadaraya-Watson estimator as in creating the observed empirical surfaces. Thus, it was possible to compare the observed empirical surfaces with the randomly permuted hypothetical surfaces and test whether the resource dependence on the observed surfaces was formed randomly or not.

\subsection{Postcode areas}

A common geographical unit applied in regional analyses is the municipality, but because each Finnish municipality, LAU 2 area, is rather heterogeneous in terms of population and demographic development, it is more valid to use smaller and more homogeneous areal units in order to observe spatial patterns within rural areas and their underlying processes. The postcode area constitutes the smallest regional statistical entity based on functionality in the distribution of a service, here the postal service. Due to data or reporting limitations, earlier studies have typically focused on the county or municipality level - a level of aggregation that may obscure important community-level relationships between the people and the use of natural resources (Mekbeb et al. 2009). This analysis differs from many earlier studies since the database used (SuomiCD m.a.) consists of the Finnish postcode areas. The postcode areas of urban municipalities were excluded from the present data and the postcode areas of the study were located in the rural core, sparsely populated rural, and urban-adjacent municipalities in 2005 (Figure 1). The rural area data set included 1,157 postcode areas. The study period 1994 - 2003 was selected to represent the growth interval of the rural economy. During that period the total number of jobs in the investigated rural postcode increased by 37,370 (Figure 2). 

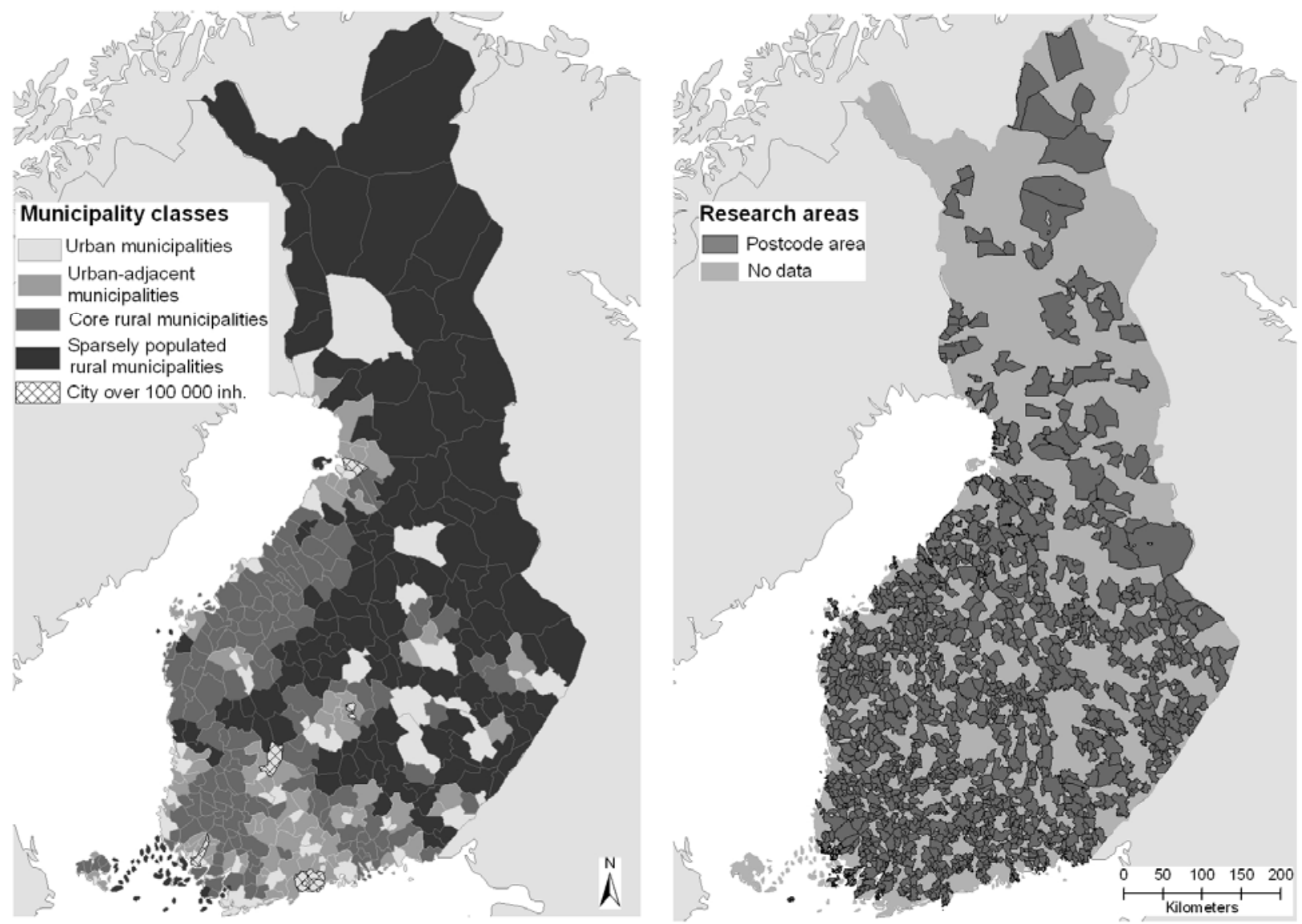

Fig 1. Municipality classes in Finland and the rural postcode areas studied. A rural postcode area is included if the majority of its surface area is located in non-urban municipality classes.

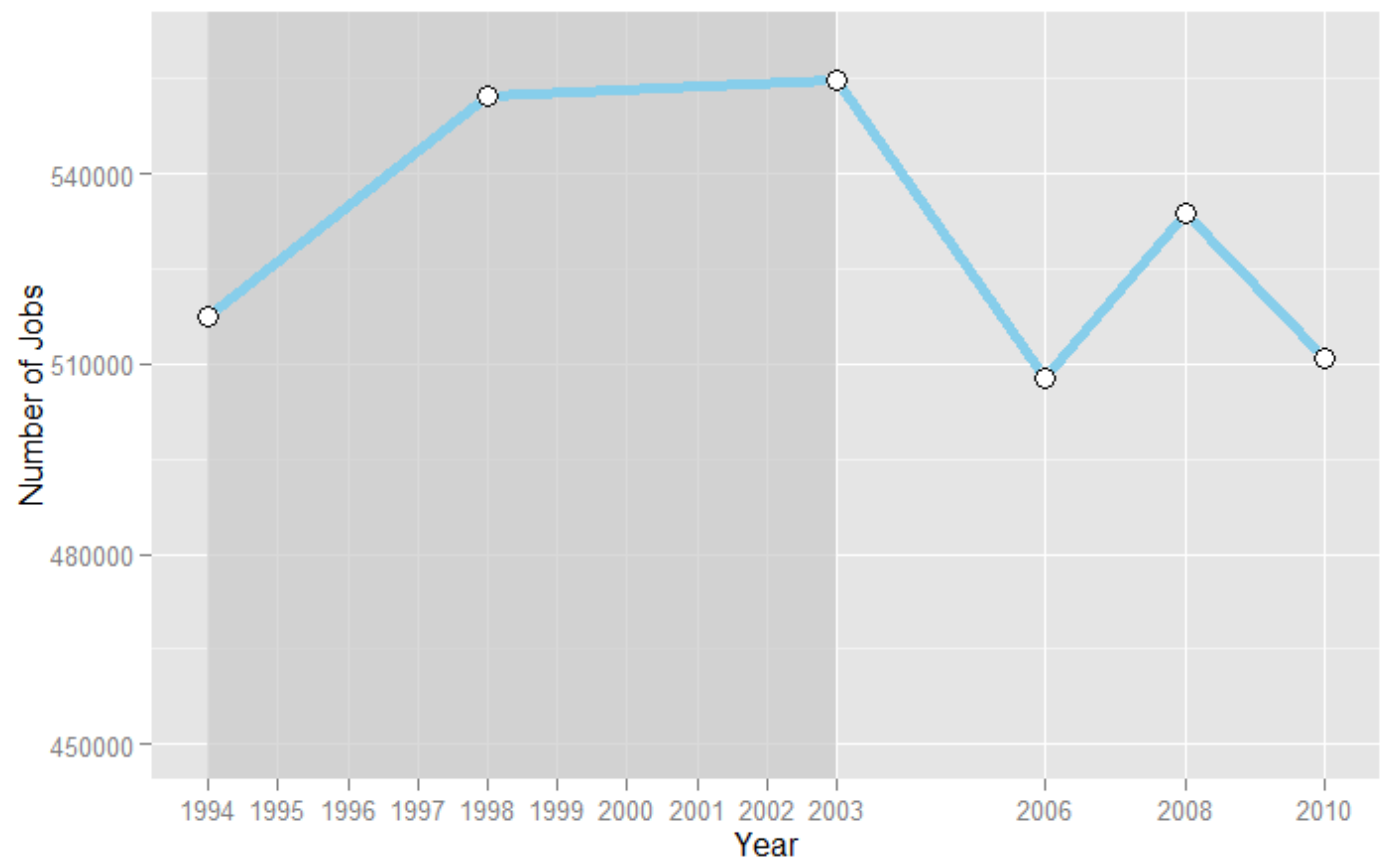

Fig 2. Growth and decline in jobs in the investigated rural postcode areas from 1994 to 2010. 


\section{Reasons for spatially unequal rural development in Finland}

\subsection{Factors explaining job creation from 1994 to 2003}

Hierarchical regression analyses were applied using the forward selection criterion and omitting the statistically insignificant variables from each model. The number of actual explanatory variables remained substantially small in spite of the large tentative set of variables (Tables 1 and 2, and Table A1 in the Appendix). Variable selection was based on the Akaike Information Criterion (e.g. Venables and Ripley 2002). The collinearity of the explanatory variables was tested using pairwise correlations and the variance inflation factor (VIF). Four independent economic variables constitute model 1, while model 2 contains two additional demographic variables and model 3 further adds three locational variables. Three variables from the amenity vector were additionally included in models 4-7. Altogether twelve variables were accepted for the models, tolerating a risk level of 0.05 . The models include the significant variables that result from the forward selection criterion. The full models 4-7 show the estimation results for the comparison of the ordinary OLS model with the spatial error models with spatial lags and the logit solution. Descriptive statistics for the selected variables are presented in Table A2 in the Appendix.

\begin{tabular}{|c|c|c|c|c|c|c|c|}
\hline & \multicolumn{6}{|c|}{ Partial models 1-3 } \\
\hline & & \multicolumn{2}{|c|}{ First OLS: economy } & \multicolumn{2}{|c|}{$\begin{array}{l}\text { Second OLS: } \\
\text { economy and } \\
\text { demography }\end{array}$} & \multicolumn{2}{|c|}{$\begin{array}{l}\text { Third OLS: } \\
\text { economy, } \\
\text { demography, and } \\
\text { location }\end{array}$} \\
\hline Vector & Variable & Coefficient & $\begin{array}{l}\text { Std } \\
\text { Error }\end{array}$ & Coefficient & $\begin{array}{l}\text { Std } \\
\text { Error }\end{array}$ & Coefficient & $\begin{array}{l}\text { Std } \\
\text { Error }\end{array}$ \\
\hline \multirow[t]{4}{*}{ Economy } & Entrepreneurs_P & 0.330 & 0.203 & $0.728^{* * *}$ & 0.198 & $0.658^{* * *}$ & 0.198 \\
\hline & $\Delta$ unemployment & $-0.258^{* * *}$ & 0.027 & $-0.205^{* * *}$ & 0.027 & $-0.198^{* * *}$ & 0.027 \\
\hline & Sqrt Herf & -4.961 & 4.973 & -7.515 & 4.775 & -7.418 & 4.755 \\
\hline & Sqrt_SLQ_primary & $-10.654^{* * *}$ & 0.617 & $-8.019 * * *$ & 0.644 & $-7.958^{* * *}$ & 0.644 \\
\hline \multirow{2}{*}{$\begin{array}{l}\text { Demo- } \\
\text { graphy }\end{array}$} & Young adults & & & $1.273^{* * *}$ & 0.288 & $1.007^{* * *}$ & 0.296 \\
\hline & Pensioners & & & $-0.696^{* * *}$ & 0.112 & $-0.707^{* * *}$ & 0.114 \\
\hline \multirow{6}{*}{$\begin{array}{l}\text { Relative } \\
\text { location }\end{array}$} & Sqrt_D_city & & & & & -0.486 & 0.269 \\
\hline & D_city100000-Dcity & & & & & -0.174 & 0.102 \\
\hline & Sqrt_Pop_city & & & & & $-0.018^{* * *}$ & 0.007 \\
\hline & Constant & $17.438^{* * *}$ & 3.112 & 12.609 * & 5.327 & $25.058^{* * *}$ & 6.145 \\
\hline & $\mathrm{R}^{2}$ & \multicolumn{2}{|l|}{0.356} & \multicolumn{2}{|l|}{0.412} & \multicolumn{2}{|l|}{0.420} \\
\hline & $\mathrm{N}$ & \multicolumn{2}{|l|}{1161} & \multicolumn{2}{|l|}{1161} & \multicolumn{2}{|l|}{1161} \\
\hline
\end{tabular}

Tab 1. Nested ordinary least squares (OLS) regression models without natural amenities explaining job creation in rural postcode areas in 1994 - 2003. For explanation of the variables, see Table $2 A$ in the Appendix.

${ }^{*}{ }^{* * *}$ significant at $p \leq 0.001,{ }^{* *}$ significant at $0.001<p \leq 0.01,{ }^{*}$ significant at $0.01<p \leq 0.05$

To illustrate the importance of the varying significance of the independent variables for job creation, a comparison of the $\mathrm{R}^{2}$ values for models $1-4$ shows that the OLS model with only economic variables alone accounts for over one-third of the total variance, while the addition of the demographic, locational, and amenity variables increases the $\mathrm{R}^{2}$ only by 5.6 percentage points (Table 1). The spatial error model was preferred to the spatial lag model based on regression diagnostics regarding Lagrange multiplier test statistics (Anselin 1988). The levels of explanation $\left(R^{2}\right)$ of the spatial error models (models 5-6) are 43 percent, i.e. slightly higher than those for the full non-autocorrelation model (Table 2). The same is true of the logit model. Because the results of the spatial error and logit models are similar to the result of the fourth OLS model, they are not interpreted in a detailed way. Autocorrelation in the attributes of rural economies is not so significant that it could substantially affect job creation. 


\begin{tabular}{|c|c|c|c|c|c|c|c|c|c|}
\hline \multirow{3}{*}{\begin{tabular}{|l} 
\\
Vector
\end{tabular}} & \multirow[b]{3}{*}{ Variable } & \multicolumn{8}{|c|}{ Full models 4-7 } \\
\hline & & \multicolumn{2}{|c|}{$\begin{array}{l}\text { Fourth OLS: all four } \\
\text { vectors }\end{array}$} & \multicolumn{2}{|c|}{$\begin{array}{l}\text { Fifth: spatial error } \\
(\mathrm{W}=20 \mathrm{~km})\end{array}$} & \multicolumn{2}{|c|}{$\begin{array}{l}\text { Sixth: spatial error } \\
(\mathrm{W}=85 \mathrm{~km})\end{array}$} & \multicolumn{2}{|c|}{ Seventh: Logit } \\
\hline & & Coefficient & $\begin{array}{l}\text { Std } \\
\text { Error }\end{array}$ & Coefficient & $\begin{array}{l}\text { Std } \\
\text { Error }\end{array}$ & Coefficient & $\begin{array}{l}\text { Std } \\
\text { Error }\end{array}$ & Coefficient & $\begin{array}{l}\text { Std } \\
\text { Error }\end{array}$ \\
\hline \multirow[t]{4}{*}{ Economy } & Entrepreneurs P & $0.777^{* * *}$ & 0.201 & $0.772^{* * *}$ & 0.198 & $0.754^{* * *}$ & 0.197 & $0.091^{* *}$ & 0.030 \\
\hline & $\Delta$ unemployment & $-0.188^{* * *}$ & 0.026 & $-0.190^{* * *}$ & 0.026 & $-0.192^{* * *}$ & 0.025 & $-0.023^{* * *}$ & 0.004 \\
\hline & Sqrt Herf & -6.415 & 4.723 & -7.015 & 4.698 & -7.622 & 4.656 & $-1.880^{* *}$ & 0.667 \\
\hline & Sqrt_SLQ_primary & $-8.049^{* * *}$ & 0.644 & $-7.996^{* * *}$ & 0.634 & $-7.846^{* * *}$ & 0.631 & $-0.910^{* * *}$ & 0.092 \\
\hline \multirow{2}{*}{$\begin{array}{l}\text { Demo- } \\
\text { graphy }\end{array}$} & Young adults & $0.978^{* *}$ & 0.297 & $1.016^{* * *}$ & 0.293 & $0.995^{* * *}$ & 0.284 & 0.129 ** & 0.046 \\
\hline & Pensioners & $-0.663^{* * *}$ & 0.114 & $-0.667^{* * *}$ & 0.111 & $-0.719^{* * *}$ & 0.108 & $-0.045^{* *}$ & 0.017 \\
\hline \multirow{3}{*}{$\begin{array}{l}\text { Relative } \\
\text { Location }\end{array}$} & Sqrt_D_city & $-0.873^{* *}$ & 0.329 & $-0.858^{* *}$ & 0.311 & $-0.774^{* *}$ & 0.291 & $-0.099 *$ & 0.047 \\
\hline & D_city100000-Dcity & $-0.383^{* *}$ & 0.115 & $-0.380^{* * *}$ & 0.106 & $-0.390^{* * *}$ & 0.086 & $-0.052^{* *}$ & 0.017 \\
\hline & Sqrt_Pop._city & -0.019 ** & 0.007 & $-0.018^{* *}$ & 0.006 & $-0.018^{* *}$ & 0.006 & $-0.002^{*}$ & 0.001 \\
\hline \multirow[t]{7}{*}{ Amenity } & Year_temp. & $-1.041^{* * *}$ & 0.273 & $-1.049^{* * *}$ & 0.255 & $-1.010^{* * *}$ & 0.206 & $-0.130^{* * *}$ & 0.040 \\
\hline & Mean_elevation & $-0.044^{* *}$ & 0.014 & $-0.043^{* * *}$ & 0.012 & $-0.042^{* * *}$ & 0.010 & $-0.005^{*}$ & 0.002 \\
\hline & Nature_reserves & $0.277^{* *}$ & 0.105 & $0.273^{* *}$ & 0.102 & $0.286^{* *}$ & 0.094 & 0.008 & 0.015 \\
\hline & Lambda & - & - & -0.074 & 0.042 & -0.454 * & 0.194 & - & - \\
\hline & Constant & $39.620 * * *$ & 6.921 & $39.397^{* * *}$ & 6.709 & $39.874^{* * *}$ & 6.245 & $4.166^{* * *}$ & 1.049 \\
\hline & $\mathrm{R}^{2}$ & \multicolumn{2}{|l|}{0.425} & \multicolumn{2}{|l|}{0.433} & \multicolumn{2}{|l|}{0.434} & \multicolumn{2}{|l|}{$0.445^{2)}$} \\
\hline & $\mathrm{N}$ & \multicolumn{2}{|l|}{1161} & \multicolumn{2}{|l|}{1161} & \multicolumn{2}{|l|}{1161} & \multicolumn{2}{|l|}{1161} \\
\hline
\end{tabular}

Tab 2. Full regression models explaining job creation in rural postcode areas in 1994 - 2003. For explanation of the variables, see Table $2 A$ in the Appendix.

1) ${ }^{* * *}$ significant at $p \leq 0.001,{ }^{* *}$ significant at $0.001<p \leq 0.01,{ }^{*}$ significant at $0.01<p \leq 0.05$

2) Nagelkerke $R^{2}$

The first hypothesis stated that rural areas have experienced spatially unequal job creation caused by local economic and demographic factors, the proximity of rural postcode areas to urban centers, and amenity factors. The findings support this hypothesis, although with fewer variables than originally expected. As indicated in Tables 1 and 2, entrepreneurship promotes job creation because the higher the proportion of non-farming entrepreneurs, the more favorable the change in the number of jobs was. Thus, such entrepreneur-rich rural areas are better than average areas and prone to job growth. The explanatory power of the percentage decrease in the unemployment level indicates that the higher the decrease in local unemployment was, the greater the job creation was. Hence, job creation absorbed unemployed labor in 1994 - 2003, but it seems to be the result of saturation in better-off rural areas in the booming period; hence, the most marginal areas benefited. Moreover, economic growth lured migrants to move into urban and urban-adjacent municipalities and no significant evening up of labor markets took place without a spatial shift of labor from the rural areas to the cities (Malinen et al. 2006: 39). Leveling off is mild and cyclical, whereupon high unemployment differences between areas and regions tend to persist.

The location quotient for primary production highly significantly explains job creation in all the models, indicating that the higher the economic specialization of a rural postcode area in primary industries was, the poorer the area performed. Local attributes related to specialization in primary production tend to retard job creation. This tendency fits the theories, which show how a stagnant sector and uncompetitive environment do not offer work but push labor to more appealing areas or, if possible, to living on welfare benefits (Lundholm 2007). Except for the results of the logit model, a diversified industrial structure is not a significant factor for job creation at the rural small-area level. This is in line with the results of the study by Hartog, Boschma, and Sotarauta (2012), which shows that industrial diversity has a positive impact on regional growth in a high-tech industry environment only and at the labor market area level. The result does not overrule the necessity that only a transformation of the mix of industries offers possibilities for compensating for jobs lost in the primary industries, but it demonstrates that Jacobs's externalities cannot be easily detected by rural small areas contrary to larger areas (van der Panne and van Beers 2008).

The proportions of young adults and pensioners within the total population are the demographic variables that explain changes in the number of jobs in rural postcode areas. The higher the proportion of young adults in rural areas, the higher was the favorable impact on job creation, whereas even more significantly an increasing proportion of pensioners had 
the opposite effect (Tables 1 and 2). Likewise, in Canada (Shearmur and Polèse 2007: 468), no significant associations between job creation and educational level were found in rural postcode areas, a spatial correlation typically found in urban environments. All the rural areas were relatively even in this respect. Similarly, a small rural area seems not to benefit from its higher population density. A young population and production activities outside the primary sector increase job growth in a rural setting, and growing postcode areas of this kind are usually located adjacent to urban municipalities.

Dependence on distance from the urban network reveals reliance on interaction with urban networks. The proximity of universities and science parks does not promote rural job creation significantly as the economic activities in these areas are not directly dependent on R\&D environments. Ski resorts affect only a few areas and camping areas are very small-scale businesses and their contributions are statistically insignificant. Distance has an impact, and the distance to the nearest city and incremental distance to a larger city are significant in full models 4-7. The goodness of fit of the two distance variables in model 3 is poorer but both are almost statistically significant. The closer a postcode area is to the nearest city, the more successful job creation in the area was, indicating positive spread effects. The coefficient depicting the impact of the population mass of the nearest city carries a negative sign, indicating the impact of the attraction of the city so that backwash effects on rural areas may prevail the larger the city is, as found by Tervo (2009) in the case of the largest cities over the period from 1970 to 2004. Proximity to the city has a positive impact on rural job creation, but the influence of urban spillover is restricted in the main by commuting distance. In Canada, the findings show wider effects because the cities are larger (Polèse and Shearmur 2004; Polèse and Shearmur 2006b). Here the impact of incremental distance reveals that a location with indirect access to a city with over 100000 inhabitants increases the growth potential for rural jobs, which refers to cities in the Finnish Capital Region and Tampere, Turku, Oulu, Jyväskylä, and Lahti, which are growing large urban areas. Better access to higher-tier services improves job creation. The spread effect from smaller cities, often located in sparsely populated regions, has become less viable in the Nordic context, as many of these, too, have faced population decline (Neubauer et al. 2007: 18-20).

Among the natural amenities and conditions, three variables of the natural environment are significant (Table 2). The negative impact of elevation indicates poorer economic performance in the rural, often hilly, inland locations in the northern and eastern parts of Finland compared with the coastal areas and plains in the southern and western parts of the country. In part this can be explained by observing that many remote inland areas that were heavily colonized and supported financially now face restructuring and thereby job losses (Granberg 1999; Stone 1973; Väisänen 1966; Yli-Jokipii and Koski 1995). When urban-centric development occurs, they cannot provide competitive business environments (Mikkonen 2002). Mature resourcebased activities withdraw and no new industries come to replace them in this niche, as their locational requirements differ greatly from what is on offer. Young people who would be the future labor force have a very high propensity to move from peripheries as they see no future in their home district (Tuhkunen 2007). The negative impact of the mean annual temperature on job creation indicates greater success for the climatically colder rural areas, presumably an effect arising from the growth of the tourism industry in the north. Conservation areas there, by the same token, promoted job creation (Table 2).

\subsection{The potential of resource-dependent postcode areas}

Because agro-forest areas have large negative residuals indicating lower than predicted growth based on the variables in regression models 4-7, the second hypothesis proposed that the degree of resource dependence may indicate that the area has additional properties that retard job creation. The poorer-than-expected potential of a resource-dependent postcode area to increase jobs was investigated by means of four non-parametric regression surfaces in terms of the regression functions of resource dependence with respect to the percentage change in the number of jobs and the residuals of regression models 4-7. The estimated surfaces reveal how resource-dependent areas are positioned in relation to the expected average development and the success of job creation (Figure 3). 
The $\Delta$ Jobs-Residual coordinates indicates a close positive correlation between job creation and residuals. When the value of the positive residual variance increases, the number of jobs will increase, and the larger the negative residual variance is, the more the rural area will lose jobs. This regular change in residuals as a function of job creation reveals that the estimated models 4-7 do not capture all the factors of job creation for different degrees of resource dependence because the distribution of residuals is not random. Growing areas grow faster than expected and declining resource-dependent areas lose more jobs than expected.

The analysis of residuals shows that Finnish rural areas have a high tendency towards that the poorer the development of job opportunities is the more the primary production dominates in an area. The surfaces thus reveal that the positive residuals in successful resource-dependent areas must be much higher, indicating an exceptional chance of success, than those in the areas that are less dependent on the natural resources given the same positive growth in the numbers of jobs. Thus, there had to be retarding non-measured properties related to resource dependence explaining why equations $4-7$ do not explain better why job creation weakens when resource dependence increases. The primary production activities in these areas are dependent on subsidies and the areas lag behind in capacities and well-being (Heikkilä and Kainulainen 2000; Karvonen 2009; Karvonen and Rintala 2004). Development in such conditions tends to consist of self-reinforcing and self-reproducing processes whereby deteriorating socio-economic conditions lead to a vicious circle of decline in rural jobs, opposite to what happens in thriving urban areas (Gløersen et al. 2005; Martin and Sunley 2006; Simmie and Martin 2010).

The non-parametric surfaces show in a concrete way how the expectations of changes in the numbers of jobs in rural areas vary due to the primary production in a particular postcode area (Figure 3). A decline of 25 percent in jobs, for instance, is expected with a zero residual in areas where the resource dependence is 35 percent, but such a decline in a zero resourcedependent area would require a residual of minus 50 percent according to models 4-6 (Figure 3 , left top and bottom panels). For a highly resource-dependent area, this job loss of 25 percent is generally to be expected, but for a zero resource-dependent area such a development would imply a crisis such as that ensuing from the closure of a factory. Even though job creation in highly resource-dependent areas was lower than in low resource-dependent areas, models 4-7 reveal that a highly resource-dependent rural area can achieve slight positive growth in jobs, in which case it will be positioned in the top-right corners of the surfaces (Figure 3). Such growing resource-dependent areas have unique competitive factors that the regression models did not capture. The outliers indicate that job growth is possible in resource-dependent Finnish rural areas if opportunities emerge, as empirically demonstrated in some studies (e.g. Copus et al. 2006). However, the growth has been rare and only directed to a limited number of areas.

In order to clarify how statistically significant these dependences are, the p-values of the perceived non-parametric regression were determined (Figure 3, top panels). Examination ${ }^{4}$ against the pseudo-significance level confirms that resource dependence, along with its underlying causes, crucially retards development, i.e. it leads to lower-than-expected job creation (Figure 3). A great portion of rural areas deviates markedly from the random situation. Job growth avoids resource dependent areas as many as 79.5 percent of the statistically significant midpoints of grid cells on the surface where jobs in a rural area have grown refer to an area that is not resource dependent and only 20.5 percent to a resource-dependent area in the OLS model (Figure 3, left top panel).

\footnotetext{
${ }^{4}$ The pseudo-significance levels reveal whether the position of the values of resource dependence in the $\Delta \mathrm{Jobs}-$ Residual coordinates is lower or higher than in a random situation. The risk level is interpreted so that if the $p$-value is under 0.10 , the resource dependence will be lower than for randomly permuted surfaces (shaded areas in Figure 2, top panels), while if the $p$-value is higher than 0.90 , the resource dependence will be higher than in a randomly permuted case with a risk below 10 percent (ibid.). Therefore, when the p-value of the observed resource dependence is below the selected significance level (here $\alpha=0.90-1=0.10$ ), it is statistically evident that the change in jobs in rural economies is influenced by resource dependence, because such relationships would be unlikely to occur randomly.
} 

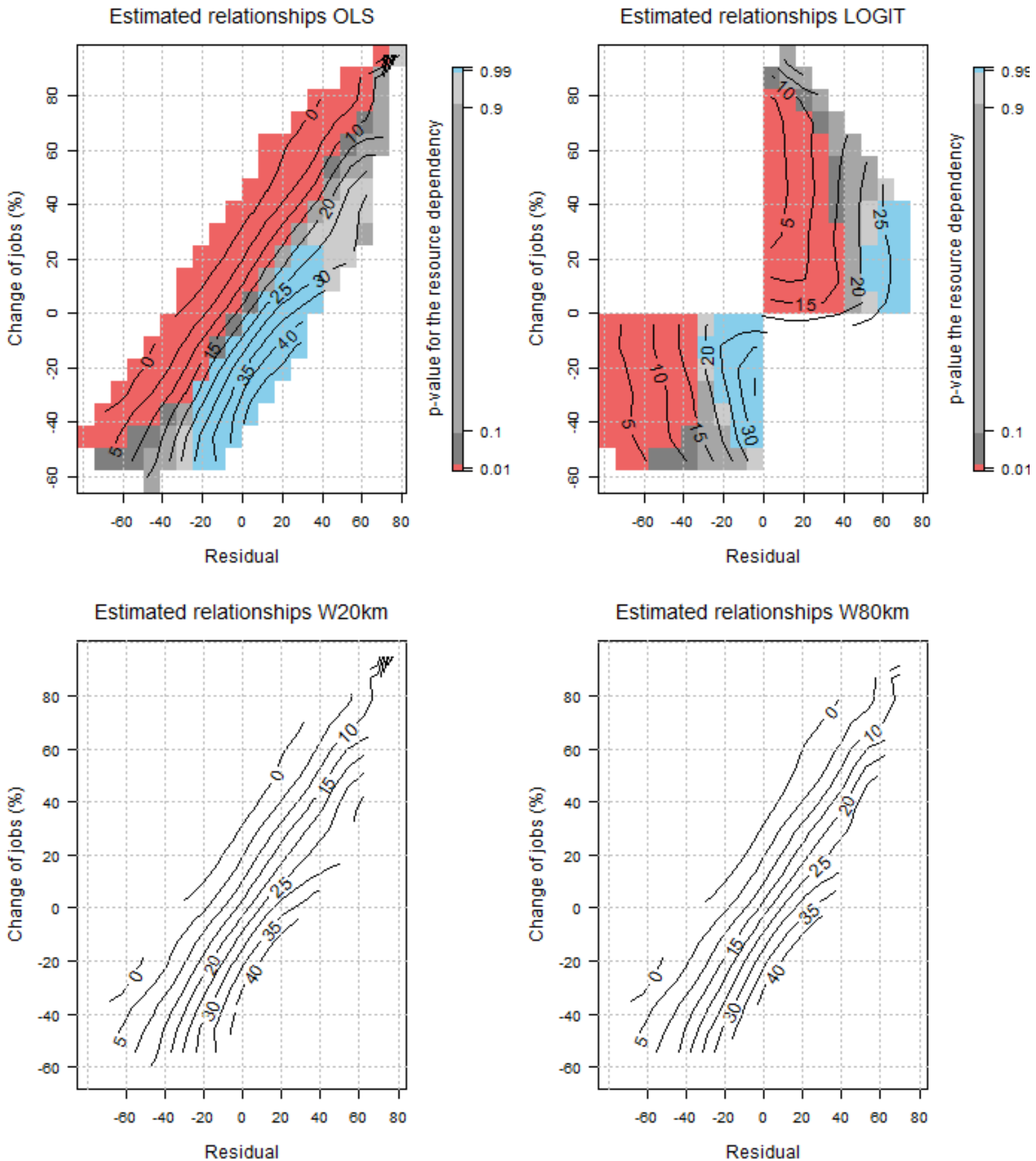

Fig 3. Explaining job creation in rural postcode areas. Estimated non-parametric regression surfaces on which resource dependence (\%) is a function of the percentage change in the number of jobs and the residuals of the regression models.

\section{Conclusions and policy recommendations}

Changes in the number of rural jobs during the period of 1994 - 2003 were associated especially with local economic conditions and with local demographic properties, natural conditions and access to urban centers. The declining rural areas are located mainly in central and eastern parts of Finland and their economy is dominated by primary production. Due to the lost jobs in agriculture and forestry in agro-forest areas, specialization in primary production explains rural decline in jobs the most. Job creation weakens systematically as resource dependence increases, indicating that lost jobs in the primary sector could not have been replaced by other industrial activities. It is obvious that rural job loss in Finland does not 
attenuate before the decline of mature industries has halted, the industrial environment has been improved, and new advantages have emerged in the agro-forest areas.

As shown in case studies (Saarinen 2003; Vatanen \& Hyppönen 2008), the growth of the tourism industry in the rural north impacted positively on job creation, and the vicinity of conservation areas, by the same token, promoted job creation. Although important for some localities, the growth in jobs in colder areas is a weak sign of the dawn of a new type of growth, it plays a minor role in job creation over the whole country. The regression analyses show that no other initial advantage or turn in development was waiting to become clearly discernible. Tourism and related services in some localities, and more generally, some service sectors and energy production have had a positive effect on employment (OECD 2008, 63-54), but those still seem to be hidden behind the employment losses in agro-forest production in many areas. New profitable business opportunities emerge from external demand and are based on general and specific competitive advantages in rural areas. As local conditions are geographically sporadic, this restructuring brings about new economic landscapes in rural areas.

To achieve growth, private and public actors and their policies should improve human capacities, accessibility and business environment and, as shown in a study (Lehtonen and Tykkyläinen 2012), push down costs in rural areas. Lagged industrial transformation challenges actors to reform rural and regional policy from sheltering to developing new initial advantages, institutional conditions and technologies that rest on the production opportunities of the rural area concerned. A development policy is successful if the industries in rural conditions can really operate on a profitable basis in the market conditions. If development measures do not lead to results locally in the longer run, stakeholders must make migration more attractive and reorganize the services and governance systems accordingly in order to attain a better economic balance in the declining rural localities.

References

[1] Anselin, L. (1988). Lagrange multiplier test diagnostics for spatial dependence and spatial heterogenity. Geographical Analysis 20(1), 1-17. Doi: 10.1111/j.1538-4632.1988.tb00159.x.

[2] Anselin, L. (1990). Spatial dependence and spatial structural instability in applied regression analysis. Journal of Regional Science, 30(2), 185-207. Doi: 10.1111/j.14679787.1990.tb00092.x.

[3] Ayres, C. (1962). The theory of economic progress, $2^{\text {nd }}$ ed. New York: Schocken Books.

[4] Bosma, N. \& Schutjens, V. (2011). Understanding regional variation in entrepreneurial activity and entrepreneurial attitude in Europe. Annals of Regional Science, 47(3), 711-742. Doi: 10.1007/s00168-010-0375-7.

[5] Bryden, J. \& Bollman, R. (2000). Rural employment in industrialised countries. Agricultural Economics, 22(2), 185 - 197. Doi: 10.1111/j.1574-0862.2000.tb00017.x.

[6] Castells, M. (2000). The rise of the network society, $2^{\text {nd }}$ ed. Oxford: Blackwell.

[7] Castells, M. \& Himanen, P. (2002). The information society and the welfare state. The Finnish model. Oxford: Oxford University Press.

[8] Cooke, P. \& De Laurentis, C. (2002). The index of knowledge economies in the European Union: Performance rankings of cities and regions. Regional Industrial Research Paper 41. Cardiff: Centre for Advanced Studies.

[9] Cooke, P. \& Leydesdorff, L. (2006). Regional development in the knowledge-based economy: The construction of advantage. Journal of Technology Transfer, 31(1), 5 - 15.| Doi: 10.1007/s10961-005-5009-3.

[10] Copus, A., Hall, C., Barnes, A., Dalton, G., Cook, P., Weingarten, P., Baum, S., Stange, H., Lindner, C., Hill, A., Eiden, G., McQuaid, R., Grieg, M. \& Johansson, M. (2006). Study on employment in rural areas (SERA), final report for the European Commission. Brussels: 
DG AGRI.

[11] Danson, M. (2009). New regions and regionalization through clusters. International Journal of Public Sector Management, 22(3), 260 - 271. Doi: 10.1108/09513550910949235.

[13] Deller, S., Tsai T.-H., Marcouiller, D. \& English, D. (2001). The role amenities and quality of life in rural economic growth. American Journal of Agricultural Economics, 83(8), 352 - 365. Doi: 10.1111/0002-9092.00161.

[14] Faraway, J. (2006). Extending the linear model with R. Generalized linear, mixed effects and nonparametric regression models. New York: Chapman and Hall/CRC.

[15] Foray, D., \& Lundvall, B. (1996). The knowledge-based economy: From the economics of knowledge to the learning economy. In Employment and growth in the knowledge-based economy (pp. 11 - 32). Paris: OECD.

[16] Gallup, J., Sachs, J. \& Mellinger, A. (1999). Geography and economic development. International Regional Science Review, 22(2), 179-232. Doi: $10.1177 / 016001799761012334$.

[17] Gløersen, E., Dubois, A., Copus, A. \& Schürmann, C. (2005). Northern peripheral, sparsely populated regions in the European north. Nordregio Report 2005: 4. Stockholm: NORDREGIO.

[18] Granberg, L. (1999). The emergence of welfare state rationality in Finnish agricultural policy. Sociologia Ruralis, 39(3), 311 - 327. Doi: 10.1111/1467-9523.00110.

[19] Hartog, M., Boschma, R. \& Sotarauta, M. (2012). The impact of related variety on regional employment growth in Finland 1993 - 2006: High-tech versus medium/low-tech. Industry and Innovation, 19(6), 459 - 476. Doi: 10.1080/13662716.2012.718874.

[20] Heikkilä, E. \& Pikkarainen, M. (2010). Differential population development in the regions of Finland, Population, Space and Place, 16(4), 323 - 334. Doi: 10.1002/psp.561.

[21] Heikkilä, M. \& Kainulainen, S. (2000). Maan sisäiset hyvinvointierot. Yhteiskuntapolitiikka, 65(6), 489 - 501.

[22] Helminen, V., Ristimäki, M. \& Oinonen, K. (2003). Etätyö ja työmatkat Suomessa. Helsinki: Edita Publishing.

[23] Hill, F. \& Gaddy, C. (2003). The Siberian curse: How communist planners left Russia out in the cold. Washington D.C.: The Brookings Institution.

[24] Hjerppe, R. (1989). The Finnish economy 1860 - 1985: Growth and structural change. Studies on Finland's Economic Growth XIII. Helsinki: Bank of Finland Publications.

[25] Hobbs, F. \& Stoops, N. (2002). Demographic trends in the $20^{\text {th }}$ century. U.S. Census Bureau, Census 2000 Special Reports, Series CENSR-4. Washington, D.C.: U.S. Government Printing Office.

[26] Irvin, E., Isserman, A., Kilkenny, M. \& Partridge, M. (2010). A century of research on rural development and regional issues. American Journal of Agricultural Economics, 92(2), 522553. Doi: $10.1093 /$ ajae/aaq008.

[27] Jauhiainen, J. (2008). Regional and Innovation Policies in Finland - Towards Convergence and/or Mismatch? Regional Studies, 42(7), 1031-1045. Doi: 10.1080/00343400701543140.

[28] Kalugina, Z. (2007). Institutional traps in agrarian transformation in Russia. Eastern European Countryside, 13(1), 69 - 82.

[29] Karvonen, S. (2009). Kuinka Suomi jakautuu 2000-luvulla? Yhteiskuntapolitiikka, 74(5), 467-484.

[30] Karvonen, S. \& Rintala, T. (2004). Alueellisten hyvinvointierojen kasvu jatkuu. Yhteiskuntapolitiikka, 69(2), 159 - 170. 
[31] Kitson, M., Martin, R. \& Tyler, P. (2004). Regional competitiveness: An elusive yet key concept? Regional Studies, 38(9), 991 - 999. Doi: 10.1080/0034340042000320816.

[32] Koski, R. (2002). Pohjalaisen yrittäjyyden synty, leviäminen ja alueellinen eriytyminen. Acta Wasaensia 101. Aluetiede 7.

[33] Kosonen, R. (1995). The role of institutions and institutional lag in transition towards indigenous local development: The case of Vyborg/Russia. Geographische Zeitschrift, 83(2), 100 - 113.

[34] Kosonen, R. (2002). Governance, the local regulation process, and enterprise adaptation process in post-socialism. The case of Vyborg. Helsinki School of Economics A-199.

[35] Krätke, S. (2007). Metropolisation of the European economic territory as a consequence of increasing specialisation of urban agglomerations in the knowledge economy. European Planning Studies, 15(1), 1 - 27. Doi: 10.1080/09654310601016424.

[36] Krugman, P. (1991). Increasing returns and economic geography. Journal of Political Economy, vol. 99, no. 3, pp. 483 - 499.

[37] Laakso, S. \& Loikkanen, S. (2004). Kaupunkitalous. Helsinki: Gaudeamus.

[38] Lehtonen, O. \& Tykkyläinen, M. (2010). Self-reinforcing spatial clusters of migration and socio-economic conditions in Finland in 1998 - 2006. Journal of Rural Studies, 26(4), 361373. Doi: 10.1016/j.jurstud.2010.02.003.

[39] Lehtonen, O. \& Markku Tykkyläinen, M. (2012). Työpaikkakehityksen alueelliset kehitysprosessit Itä-Suomessa 1994 - 2003. Terra 123(2), 85 - 105.

[40] Lindstrom, D. E. (1964). Influence of rural institutions on economic development. Illinois Agricultural Economics, 4(3), 85 - 93.

[41] Lundholm, E. (2007). New motives for migration? On interregional mobility in the Nordic countries [doctoral thesis]. Umeå University.

[42] Malinen, P. Kytölä, L., Keränen, H. \& Keränen, R. (2006). Suomen maaseututyypit 2006. Maa- ja metsätalousministeriö 7/2006.

[43] Markey, S., Halseth, G. \& Manson, D. (2006). The struggle to compete: From comparative to competitive advantage in Northern British Columbia. International Planning Studies, 11(1), 19 - 39. Doi: 10.1080/13563470600935016.

[44] Martin, R. \& Sunley, P. (2006). Path dependency and regional economic evolution. Journal of Economic Geography, 6(4), 395 - 437. Doi: 10.1093/jeg/lbl012.

[45] Maskell, P. \& Malmberg, A. (1999). Localised learning and industrial competitiveness. Cambridge Journal of Economics, 23(2), 167-185. Doi: 10.1093/cje/23.2.167.

[46] Mekbeb, E., Lilieholm, R., Blahna, D. \& Kruger, L. (2009). Resource use, dependence and vulnerability: Community-resource linkages on Alaska's Tongass National Forest. WTI Transactions on Ecology and the Environment, 122(1), 263-272. Doi: 10.2495/ECO090251.

[47] Mikkonen, K. (2002). Competitive advantage of regions and small economic areas: The case of Finland. Fennia, 180(1-2), 191 - 198.

[48] Neubauer, J., Dubois, A., Hanell, T., Lähteenmäki-Smith, K., Pettersson, K., Roto, J. \& Steineke, M. (2007). Regional development in the Nordic Countries. Nordregio Report 2007: 1. Stockholm: NORDREGIO.

[49] North, D. (1991). Institutions. Journal of Economic Perspectives, 5(1), 97 - 112.

[50] OECD. (1996). The knowledge-based economy. Paris: OECD.

[51] OECD. (2008). Rural policy reviews: Finland. Paris: OECD.

[52] OECD. (2009). Main science and technology indicators 2009-1. Paris: OECD. 
[53] Olfert, M. \& Partridge, M. (2010). Best practices in twenty-first-century rural development and policy. Growth and Change, 41(2), 147 - 164. Doi: 10.1111/j.1468-2257.2010.00523.x.

[54] Overdevest, C. \& Green, G. (1995). Forest dependence and community well-being: A segmented market approach. Society \& Natural Resources: An International Journal, 8(2), 111 - 131. Doi: 10.1080/08941929509380906.

[55] van der Panne, G. \& van Beers, C. (2008). On the Marshall-Jacobs controversy: It takes two to tango. Industrial and Corporate Change, 17(5), 1049-1070. Doi: 10.1093/icc/dtn029.

[56] Partridge, M. (2010). The dueling models: NEG vs. amenity migration in explaining US engines of growth. Papers in Regional Science, 89(3), 513 - 536. Doi: 10.1111/j.14355957.2010.00315.x.

[57] Partridge, M., Bollman, R., Olfert, M., Rose, M. \& Alasia, A. (2007). Riding the wave of urban growth in the countryside: Spread, backwash, or stagnation? Land Economics, 83(2), 128 - 152.

[58] Partridge, M., Olfert, M. \& Alasia, A. (2007). Canadian cities as regional engines of growth: Agglomeration and amenities. Canadian Journal of Economics, 40(1), 39 - 68.

[59] Partridge, M., \& Rickman, D. (2008). Distance from urban agglomeration economies and rural poverty. Journal of Regional Science, 48(2), 285-310. Doi: 10.1111/j.14679787.2008.00552.x.

[60] Partridge, M., Rickman, D., Kamar, A. \& Olfert, M. (2008a). Lost in space: Population growth in the American hinterlands and small cities. Journal of Economic Geography, 8(6), 727 - 757. Doi: 10.1093/jeg/lbn038.

[61] Partridge, M., Rickman, D., Kamar, A. \& Olfert, M. (2008b). Employment growth in the American urban hierarchy: Long live distance. The B. E. Journal of Macroeconomics, 8(1), 1 - 36. Doi: 10.2202/1935-1690.1627.

[62] Partridge, M., Rickman, D., Kamar, A. \& Olfert, M. (2009). Agglomeration spillovers and wage and housing cost gradients across the urban hierarchy. Journal of International Economics, 78(1), 126 - 140. Doi: 10.1016/j.jinteco.2009.02.004.

[63] Patriquin, M., Parkins, J. \& Stedman, R. (2007). Socio-economic status of boreal communities in Canada. Forestry, 80(3), 279 - 291. Doi: 10.1093/forestry/cpm014.

[64] Pekkala, S. (2003). What draws people to urban growth centers: Jobs vs. pay. VATT Discussion Papers 310.

[65] Piipponen, M. (2006). Working community structures and employee generations: Three mill communities of northwest Russia in the 1990s. Aleksanteri Papers 2:2006. Helsinki: Kikimora.

[66] Polèse, M., \& Shearmur, R. (2004). Is distance really dead? Comparing location patterns over time in Canada. International Regional Science Review, 27(4), 431 - 457. Doi: $10.1177 / 0160017604267637$.

[67] Polèse, M. \& Shearmur, R. (2006a). Why some regions will decline: A Canadian case study with thoughts on local development strategies. Papers in Regional Science, 85(1), 23 - 46. Doi: 10.1111/j.1435-5957.2006.00024.x.

[68] Polèse, M. \& Shearmur, R. (2006b). Growth and location of economic activity: The spatial dynamics of industries in Canada 1971-2001. Growth and Change, 37(3), 362 - 395. Doi: 10.1111/j.1468-2257.2006.00328.x.

[69] Puga, D. (2002). European regional policies in light of recent location theories. Journal of Economic Geography, 2(4), 373 - 406. Doi: 10.1093/jeg/2.4.373.

[70] Pyöriä, P., Melin, H. \& Blom, R. (2005). Knowledge workers in the information society. Tampere: Tampere University Press. 
[71] Raiser, M. (2001). Informal institutions, social capital, and economic transition: Reflections on a neglected dimension (pp. 218 - 240). In Cornia, G. A. \& Popov, V., ed., Transition and institutions: The experience of gradual and late reformers. Oxford: Oxford University Press.

[72] Rodriquez-Pose, A. \& Frateri, U. (2007). Regional business cycles and the emergence of sheltered economies in the southern periphery of Europe. Growth and Change, 38(4), 621648. Doi: 10.1111/j.1468-2257.2007.00390.x.

[73] Ruttan, V. \& Hayami, Y. (1984). Toward a theory of induced institutional innovation. Journal of Development Studies, 20(4), 203 - 223. Doi: 10.1080/00220388408421914.

[74] Saarinen, J. (2003). The Regional Economics of Tourism in Northern Finland: The Socioeconomic Implications of Recent Tourism Development and Future Possibilities for Regional Development. Scandinavian Journal of Hospitality and Tourism, 3(2), 91 - 113. Doi: $10.1080 / 15022250310001927$.

[75] Sachs, J. \& Warner, A. (1997). Fundamental sources of long-run growth. American Economic Review, 87(2), 184 - 188.

[76] Simmie, J. \& Martin, R. (2010). The economic resilience of regions: Towards an evolutionary approach. Cambridge Journal of Regions, Economy and Society, 3(1), 2743. Doi: 10.1093/cjres/rsp029.

[77] Shearmur, R. \& Polèse, M. (2007). Do local factors explain local employment growth? Evidence from Canada, 1971-2001. Regional Studies, 41(4), 453-471. Doi: $10.1080 / 00343400600928269$.

[78] Stedman, R., Parkins, J. \& Beckley, T. (2004). Resource dependence and community wellbeing in rural Canada. Rural Sociology, 69(2), 213-234. Doi: 10.1526/003601104323087589.

[79] Stedman, R., Parkins, J. \& Beckley, T. (2005). Forest dependence and community wellbeing in rural Canada: Variation by forest sector and region. Canadian Journal of Forest Research. 35(1), 215 - 220. Doi: 10.1139/x04-140.

[80] Stenholm, P., Acs, Z. \& Wuebker, R. (2013). Exploring country-level institutional arrangements on the rate and type of entrepreneurial activity. Journal of Business Venturing, 28(1), 176 - 193. Doi: 10.1016/j.jbusvent.2011.11.002.

[81] Stephens, H. \& Partridge, M. (2011). Do entrepreneurs enhance economic growth in lagging regions? Growth and Change, 42(4), 431-465. Doi: 10.1111/j.14682257.2011.00563.x.

[82] Stone, K. H. (1973). Northern Finland's post-war colonizing and emigration. A geographical analysis of rural demographic counter-currents. European demographic monographs. The Hague: Martinus Nijhoff.

[83] SuomiCD. (m.a.) Data base. Helsinki: Statistics Finland.

[84] Suorsa, K. (2007). Regionality, innovation policy and peripheral regions in Finland, Sweden and Norway. Fennia, 185(1), 15 - 29.

[85] Terluin, I. (2003). Differences in economic development in rural regions of advanced countries: An overview and critical analysis of theories. Journal of Rural Studies, 19(3), 327-344. Doi: 10.1016/S0743-0167(02)00071-2.

[86] Terluin, I. \& Post, J. (2000). Employment dynamics in rural Europe. Wallingford: CABI Publishing.

[87] Tervo, H. (2005). Regional policy lessons from Finland (pp. 267-282). In Felsenstein, D. \& Portnov, B. A., eds., Regional disparities in small countries, Berlin: Springer-Verlag.

[88] Tervo, H. (2009). Centres and peripheries in Finland: Granger causality tests using panel data. Spatial Economic Analysis, 4(4), 377 - 390. Doi: 10.1080/17421770903317652. 
[89] Tervo, H. (2010). Cities, hinterlands and agglomeration shadows: Spatial developments in Finland during 1880-2004. Exploration in Economic History, 47(4), 476-486. Doi: 10.1016/j.eeh.2010.05.002.

[90] Tuhkunen, A. (2007). Between location and a sense of place. Acta Universitatis Tamperensis.

[91] Väisänen, P. O. (1966). Asutustilojen alueellisesta jakaantumisesta vuoden 1959 maatalouslaskennan mukaan. Asutustoiminnan aikakauskirja,19(3), 5 - 11.

[92] Vartiainen, P. \& Viiri, A. (2002). Universities and their local partners. Industry and Higher Education, 16(2), 83 - 89. Doi: 10.5367/000000002101296153.

[93] Vatanen, E. \& M. Hyppönen (2008). Pallas-Yllästunturin kansallispuiston investointien vaikutukset Tunturi-Lapin paikallistalouteen. Maaseudun uusi aika, 16(3), 24 - 41.

[94] Venables, W. N. \& Ripley, B. D. (2002). Modern applied statistics with S, $4^{\text {th }}$ ed. Berlin: Springer.

[95] Voutilainen, O., Vihinen, H. \& Wuori, O. (2009). Maatalous, maaseutu ja tukien kohdentuminen. MTT Kasvu 7.

[96] Yli-Jokipii, P. \& Koski, A. (1995). The changing pattern of Finnish regional policies. Fennia, 173(2), $53-67$. 


\section{Appendix}

Table A1. The tentative variables included initially in the explanatory vectors $(n=1157)$.

\begin{tabular}{|c|c|c|c|}
\hline Variable & Description & Unit & Vector \\
\hline I_income & Index of median income in 2004 & & ECONOMY \\
\hline$\overline{\Delta l}$ Iincome & $\begin{array}{l}\text { Change in the index of median income in } \\
1994-2003\end{array}$ & $\%$ & ECONOMY \\
\hline Unemployment & Unemployment rate in 2003 & $\%$ & ECONOMY \\
\hline$\Delta$ unemployment & $\begin{array}{l}\text { Percentage change in the unemployment } \\
\text { rate in 1994-2003 }\end{array}$ & $\%$ & ECONOMY \\
\hline Sqrt_Herf & $\begin{array}{l}\text { Square root of the Herfindahl index } \\
\text { measuring the concentration of industries } \\
\text { by their respective shares of the total } \\
\text { production in } 2003\end{array}$ & & ECONOMY \\
\hline Dummy_Herf & $\begin{array}{l}\text { Dummy representing spatial clustering of } \\
\text { the square root of the Herfindahl index in } \\
2003\end{array}$ & & ECONOMY \\
\hline Sqrt_SLQ_primary & $\begin{array}{l}\text { Square root of the SLQ for primary } \\
\text { industries in } 2003\end{array}$ & & ECONOMY \\
\hline Sqrt_SLQ_secondary & $\begin{array}{l}\text { Square root of the SLQ for secondary } \\
\text { industries in } 2003\end{array}$ & & ECONOMY \\
\hline Dummy_secondary & $\begin{array}{l}\text { Dummy representing the spatial clustering } \\
\text { of the square root of the SLQ for } \\
\text { secondary industries in } 2003\end{array}$ & & ECONOMY \\
\hline Entrepreneurs_P & $\begin{array}{l}\text { Proportion of persons aged 18-74 having } \\
\text { self-employed person's pension insurance } \\
\text { (excl. farmers) during the last week of } \\
2003 \text {. }\end{array}$ & $\%$ & ECONOMY \\
\hline Sqrt Populatio & Square root of the population in 2003 & Inhabit. & DEMOGRAPHY \\
\hline Pop_density & Population density in 2003 & $\mathrm{lnh} . / \mathrm{km}^{2}$ & DEMOGRAPHY \\
\hline D_Pop_density & $\begin{array}{l}\text { Dummy representing the spatial clustering } \\
\text { of population density in } 2003\end{array}$ & & DEMOGRAPHY \\
\hline Highedu & $\begin{array}{l}\text { Percentage of persons with a higher } \\
\text { education in } 2003\end{array}$ & $\%$ & DEMOGRAPHY \\
\hline Mean_age & Mean age of the inhabitants in 2003 & Year & DEMOGRAPHY \\
\hline Womens & Proportion of women in 2003 & $\%$ & DEMOGRAPHY \\
\hline Children & $\begin{array}{l}\text { Proportion of children aged } 0-17 \text { years to } \\
\text { total population in } 2003\end{array}$ & $\%$ & DEMOGRAPHY \\
\hline Pensioners & $\begin{array}{l}\text { Proportion of pensioners to inhabitants } \\
\text { aged over } 17 \text { years in } 2003\end{array}$ & $\%$ & DEMOGRAPHY \\
\hline Young adults & $\begin{array}{l}\text { Proportion of inhabitants aged } 25-34 \\
\text { years to total population in } 2003\end{array}$ & $\%$ & DEMOGRAPHY \\
\hline D_skiresort & Distance from a ski resort & $\mathrm{Km}$ & LOCATION \\
\hline D camping & Distance from a camping area & $\mathrm{Km}$ & LOCATION \\
\hline D_university & Distance from a university & $\mathrm{Km}$ & LOCATION \\
\hline D_science & Distance from a science park & $\mathrm{Km}$ & LOCATION \\
\hline Sqrt_D_city & $\begin{array}{l}\text { Square root of the distance from the } \\
\text { nearest city }\end{array}$ & $\mathrm{Km}$ & LOCATION \\
\hline Sqrt_Pop_city & $\begin{array}{l}\text { Square root of the population of the } \\
\text { nearest city }\end{array}$ & Inhabit. & LOCATION \\
\hline$\Delta$ Pop $^{*}$ distance & $\begin{array}{l}\text { Population development } 1994-2003 \text { of the } \\
\text { nearest city } \times \text { distance from the nearest } \\
\text { city }\end{array}$ & & LOCATION \\
\hline Sqrt_ $\Delta$ job*distance $^{*}$ & $\begin{array}{l}\text { Square root of job development in the } \\
\text { nearest city in } 1994-2003 \times \text { distance from } \\
\text { the nearest city }\end{array}$ & & LOCATION \\
\hline$\Delta$ income ${ }^{\star}$ distance & $\begin{array}{l}\text { Change in the median income for the } \\
\text { nearest city in } 1994-2003 \times \text { distance from } \\
\text { the nearest city }\end{array}$ & & LOCATION \\
\hline$\Delta$ Popcity_post & Difference in population growth rate & $\%$ & LOCATION \\
\hline
\end{tabular}




\begin{tabular}{|c|c|c|c|}
\hline & $\begin{array}{l}\text { between the nearest city and the postcode } \\
\text { area in 1994-2003 }\end{array}$ & & \\
\hline$\Delta$ jobcity_post & $\begin{array}{l}\text { Difference in the growth rate in jobs } \\
\text { between the nearest city and the postcode } \\
\text { area in 1994-2003 }\end{array}$ & $\%$ & LOCATION \\
\hline D_city100000 & $\begin{array}{l}\text { Distance from the nearest city of over } \\
100000 \text { inhabitants (population 2003) }\end{array}$ & $\mathrm{Km}$ & LOCATION \\
\hline$\Delta$ Pop $^{*}$ distance 100000 & $\begin{array}{l}\text { Population development of the nearest city } \\
\text { of over } 100000 \text { inhabitants } \times \text { distance } \\
\text { from that city }\end{array}$ & $\%$ & LOCATION \\
\hline$\Delta$ job*distance $100000^{*}$ & $\begin{array}{l}\text { Job development of the nearest city of } \\
\text { over } 100000 \text { inhabitants } \times \text { distance from } \\
\text { that city }\end{array}$ & $\%$ & LOCATION \\
\hline$\Delta$ income* distance 100000 & $\begin{array}{l}\text { Change in the median income of the } \\
\text { nearest city of over } 100000 \text { inhabitants } \times \\
\text { distance from that city }\end{array}$ & & LOCATION \\
\hline$\Delta$ Popcity_post & $\begin{array}{l}\text { Difference in the population growth rate } \\
\text { between the nearest city of over } 100000 \\
\text { inhabitants and the postcode area }\end{array}$ & $\%$ & LOCATION \\
\hline$\Delta$ jobcity_post & $\begin{array}{l}\text { Difference in the growth rate in jobs } \\
\text { between the nearest city of over } 100000 \\
\text { inhabitants and the postcode area }\end{array}$ & $\%$ & LOCATION \\
\hline D_city100000-Dcity & $\begin{array}{l}\text { Incremental distance: distance from the } \\
\text { nearest city to a city of over } 100000 \\
\text { inhabitants }\end{array}$ & $\mathrm{Km}$ & LOCATION \\
\hline Pop_city 100000 & $\begin{array}{l}\text { Population of the nearest city of over } \\
100000 \text { inhabitants }\end{array}$ & $\begin{array}{l}\text { inhabita } \\
\text { nts }\end{array}$ & LOCATION \\
\hline Heat_sum & $\begin{array}{l}\text { Average of the effective temperature sum } \\
1980-2000\end{array}$ & ${ }^{\circ} \mathrm{C}$ & AMENITY \\
\hline Year_temp & Mean annual temperature $1980-2000$ & ${ }^{\circ} \mathrm{C}$ & AMENITY \\
\hline Mean_elevation & Mean elevation & $\mathrm{M}$ & AMENITY \\
\hline Sd_elevation & Standard deviation of the elevation & $\mathrm{M}$ & AMENITY \\
\hline Dens_pop_area & Proportion of densely populated area & $\%$ & AMENITY \\
\hline Forest & Forest as a proportion of the total area & $\%$ & AMENITY \\
\hline Fields & Fields as a proportion of the total area & $\%$ & AMENITY \\
\hline Unproductive & $\begin{array}{l}\text { Unproductive land as a proportion of the } \\
\text { total area }\end{array}$ & $\%$ & AMENITY \\
\hline Water & $\begin{array}{l}\text { Water areas as a proportion of the total } \\
\text { area }\end{array}$ & $\%$ & AMENITY \\
\hline Cottage & $\begin{array}{l}\text { Number of summer cottages per head of } \\
\text { population }\end{array}$ & & AMENITY \\
\hline D_Cottage & $\begin{array}{l}\text { Dummy variable representing the spatial } \\
\text { clustering of summer cottages }\end{array}$ & & \\
\hline Hikingroute & Length of hiking routes in the area & $\mathrm{Km}$ & AMENITY \\
\hline Nature_reserves & $\begin{array}{l}\text { Area subject to nature conservation as a } \\
\text { proportion of the total land area }\end{array}$ & $\mathrm{Km}^{2}$ & AMENITY \\
\hline
\end{tabular}


Table A2. Descriptive statistics for the dependent and independent variables $(n=1157)$.

\begin{tabular}{|l|l|r|r|r|r|}
\hline $\begin{array}{l}\text { Abbreviation of } \\
\text { the variable }\end{array}$ & Explanation & Mean & \multicolumn{1}{l|}{ SD } & Min. & Max. \\
\hline$\Delta$ Jobs & $\begin{array}{l}\text { Percentage change in the number of } \\
\text { jobs in 1994-2003 }\end{array}$ & -1.41 & 22.77 & -65.26 & 77.72 \\
\hline Entrepreneurs_P & $\begin{array}{l}\text { Entrepreneurs as a proportion of the } \\
\text { working population }\end{array}$ & 8.51 & 2.712 & 0.00 & 19.00 \\
\hline$\Delta$ unemployment & $\begin{array}{l}\text { Percentage change in the } \\
\text { unemployment rate in 1994-2003 }\end{array}$ & -26.51 & 19.98 & -81.25 & 53.84 \\
\hline Sqrt_Herf & $\begin{array}{l}\text { Square root of the Herfindahl index } \\
\text { for all industries }\end{array}$ & 0.51 & 0.13 & 0.31 & 0.95 \\
\hline Sqrt_SLQ_primary & $\begin{array}{l}\text { Square root of the SLQ for primary } \\
\text { production industries }\end{array}$ & 2.42 & 1.08 & 0.09 & 4.61 \\
\hline Young adults & $\begin{array}{l}\text { Proportion of inhabitants aged 25- } \\
\text { 34 years }\end{array}$ & 8.58 & 2.33 & 1.00 & 17.00 \\
\hline Pensioners & $\begin{array}{l}\text { Percentage of inhabitants aged over } \\
\text { 65 years }\end{array}$ & 18.97 & 5.72 & 3.00 & 39.00 \\
\hline Sqrt_D_city & $\begin{array}{l}\text { Square root of the distance from the } \\
\text { nearest city }\end{array}$ & 6.80 & 2.19 & 2.24 & 20.00 \\
\hline $\begin{array}{l}\text { D_city100000- } \\
\text { Dcity }\end{array}$ & $\begin{array}{l}\text { Incremental distance: distance from } \\
\text { the nearest city to a city of over } \\
\text { 100 000 inhabitants }\end{array}$ & 15.53 & 5.65 & 3.46 & 29.73 \\
\hline Sqrt_Pop_city & $\begin{array}{l}\text { Square root of the population of the } \\
\text { nearest city }\end{array}$ & 191.38 & 73.59 & 39.47 & 473.53 \\
\hline Year_temp & Mean annual temperature & 93.08 & 50.57 & 2.619 & 329.51 \\
\hline Mean_elevation & Mean elevation & 6.18 & 3.00 & 0.35 & 20.17 \\
\hline Nature_reserves & $\begin{array}{l}\text { Area subject to nature conservation } \\
\text { as a proportion of the total land area }\end{array}$ & 1.45 & 4.975 & 0 & 51.00 \\
\hline
\end{tabular}

